\title{
Investment Banking and Security Market Development: Does Finance Follow Industry?
}

\author{
Bharat N. Anand* \\ Alexander Galetovic ${ }^{\dagger}$ \\ Harvard University \\ Universidad de Chile
}

March 2002

\begin{abstract}
Long-term relationships between business firms and investment banks are pervasive in developed security markets and there is evidence that better monitoring and information result from these relationships. Therefore, security markets should allocate resources better when an investment banking industry exists. We study the necessary conditions for the emergence of sustainable relationships and explore whether policy can foster them. We show that policy can help alleviate the costs of relationships, but an investment banking industry will not emerge with only a small number of large firms.
\end{abstract}

JEL Classification Numbers: G20; L22

Keywords: relationships; size distribution of firms, sunk costs

* Harvard Business School, Soldiers Field Road, Boston, MA 02163. Phone: (617) 495-5082; Fax: (617) 4950355; email: banand@hbs.edu. Anand gratefully acknowledges the financial support of the Division of Research at Harvard Business School.

$\dagger$ Centro de Economia Aplicada (CEA), Av. Republica 701, Santiago, Chile. Phone: +56/2-678-4065; Fax: +56/2-689-7895; email: agaleto@dii.uchile.cl. Galetovic gratefully acknowledges the financial support of Fondecyt, Fundación Andes, the Hewlett Foundation and the Mellon Foundation. Part of this research was done while Galetovic was a Visiting Scholar at the IMF Institute. The Institute's hospitality is gratefully acknowledged. 


\section{Introduction and motivation}

By now there is quite compelling evidence that security market development not only correlates with economic growth, but also causes it. ${ }^{1}$ But what are the mechanics of this causal relationship? This paper looks at one piece of the mechanics, the industrial organization of the investment banking industry, from the perspective of firms' financing. ${ }^{2,3}$ While the literature tends to make a sharp distiction between bank- and market-based financial systems, we start from the observation that long-term relationships between firms and investment banks are pervasive in developed security markets, in particular the United States. Since a vast literature argues that better monitoring and information result from relationships, it is reasonable to think that security markets allocate resources better when an investment banking industry exists. On the contrary, when these intermediaries do not emerge, the development of the security market is likely to be hindered. We study the conditions that must be met for sustainable relationships and then explore whether policy can do something to foster them. Our conclusion is mixed. While policy can probably remove obstacles that increase the costs of relationships, the size-distribution of business firms determines whether an investment banking industry is feasible: it will not emerge if large firms are few. In this sense, 'finance follows industry'. Large firms can escape this limitation, however, by listing in foreign developed security markets.

The central theme of the paper is that the structure of an investment banking industry and its feasibility is largely determined by three characteristics of any relationship established by an investment bank and a firm: (i) the investment bank incurs a sunk set up cost to establish a relationship $^{4}$; (ii) the firm pays the investment bank only when it makes a deal ${ }^{5}$; and (iii) to a significant degree the investment bank cannot prevent other banks from free riding on the information created by the relationship (that is, information is not excludable). It can be easily seen that such an industry cannot be perfectly competitive because investment banks would free ride on each other's information. Strong price competition would then drive the fee paid by each firm below what is needed to cover sunk relationship-specific investments. In fact, we show that relationships can emerge in equilibrium only if the industry is an oligopoly of investment banks that repeatedly interact and voluntarily refrain from free riding. In addition, the technology of intermediation

\footnotetext{
${ }^{1}$ See, for example, Levine and Zervos (1998), Rousseau and Wachtel (2000), and Khan and Senhadji (2001).

${ }^{2}$ Activities of investment banks can be classified into three broad categories: (i) investment banking services; (ii) trading and principal investments; (iii) asset management and security services (see Wilhelm and Downing [forthcoming, ch. 3]). In this paper our focus is on investment banking services, which comprise equity and debt underwriting, financial restructuring, and merger and acquisitions (M\&As) advisory services - that is, those that directly affect firm financing.

${ }^{3}$ Sometimes, investment banks are referred to as 'firms'. To avoid confusion, in what follows we reserve the term 'firm' to business firms or corporations.

${ }^{4}$ This is frequently referred to as a 'relationship-specific investment.' See Williamson (1979).

${ }^{5} \mathrm{By}$ 'deal' we mean, for example, a security flotation, a merger, an acquisition, etc.
} 
imposes further restrictions on industry structure that materialize in three key conditions, which can be used to interpret several facts of the industry and systematically explore the consequences of policy-induced changes.

The first condition, which is quite standard in repeated games, is a cooperation inequality. At any moment, investment banks compare the present value of continued cooperation with the shortterm gains of cheating by undercutting. We show that free riding makes cheating very profitable and this leaves room for only a few investment banks in the industry. But contrary to standard repeated games, here cooperation is necessary for the industry to exist; the alternative is not a competitive market. The inequality further implies that these banks must have similar market shares: on the one hand a small bank would have incentives to increase its market share by cheating. On the other hand, should one investment be dominant, the rest would make small profits cooperating and prefer free riding. Similar market shares also imply a maximum number of investment banks that can coexist (i.e. a lower bound on industry concentration). A key prediction is that this number does not fall when the market grows, and we show that the model is consistent with evidence from US. underwriting and M\&As.

The second condition implies that relationships are for business firms that generate large volumes of deals, because sunk set up costs introduce scale economies at the level of each relationship (that is, at the local level). Since these set up costs are incurred by investment banks, they will not establish relationships with firms that generate small levels of deals. To be sure, firms with small volumes of deals may get investment banking services nonetheless. In fact, in the United States there is a large number of small investment banks, which are less 'prestigious' than the top 'bulge bracket' investment banks, that serve smaller firms. Nevertheless these services are probably different, because most of the time they are provided on an arm's length basis, not via relationships. In fact, we show that in a precise sense arm's length investment banking neither competes with relationship investment banking nor affects fees paid by business firms that generate large volumes of deals.

The third condition indicates that aggregate profits made from relationships must be large enough to cover the entry costs of individual banks into the industry. Thus, when the market is small, industry-level entry costs may prevent relationships from emerging. As discussed below in section 4, policy and regulations can influence the size of the relevant market. Broadly speaking, policies that reduce entry costs (e.g. allowing foreign investment banks to enter the domestic market), foster deal volume (e.g. lifting restrictions on asset sales), or reduce the costs of setting up relationships (e.g. allowing commercial banks into underwriting), will enlarge the relevant market. But, since ultimately deal volume depends on the (physical) size of the firm, relationships can emerge only in markets endowed with many large firms, because only then aggregate volumes will be large enough to pay the costs of setting up an industry. Since the size distribution of business firms 
depends heavily on an economy's structural characteristics, there are fundamental limitations to what policy can do to foster relationship investment banking. Of course, this endowment constraint is irrelevant in an economy like the United States; but it may be quite important in many developing countries. Thus, to the extent that relationships are necessary for better monitoring and information creation, economies with few large firms will have less effective security markets.

The second and third condition highlight the role of sunk costs in the development of security markets. The literature has suggested that the sunk costs of establishing a stock market may retard financial development in poor economies (see, for example, Greenwood and Jovanovic [1990], Greenwood and Smith [1993], Levine [1992] and Saint Paul [1992]). Here we argue that the relevant sunk costs are probably located at the level of the intermediaries that make securities markets work, both at the local level (the sunk costs of establishing firm-intermediary relationships) and at the aggregate level (the costs of establishing intermediaries). Doing so highlights the importance of the size distribution of firms in the development of security marktes. Moreover, the distinction between local and aggregate sunk costs suggests that large firms in a small economy need not be excluded from developed security markets. A sufficiently large firm from a small economy can establish relationships with investment banks by listing in a developed security market (e.g. the Chilean telecomm company CTC lists its security in New York). Thus, our analysis suggests that lifting restrictions to foreign capital to enter the domestic stock market is quite different from allowing domestic firms to list abroad. Long-term relationships will be established only when foreign listings are allowed.

Before proceeding, we call attention to a caveat. As said before, in this paper we seek to understand the industrial organization of investment banking-i.e., how the technology of production of investment banking services shapes market structure, thus determining equilibrium prices and quantities. To do so we concentrate on the fundamental economics of the technology, i.e., we identify the key nonconvexities. ${ }^{6}$ We are well aware that this abstracts away many complexities of the investment banking business like syndicates, product innovation, heterogeneity of products and services, or investment bank differentiation. Also, we take as given some of the key features of firminvestment bank relationships which have been identified by practitioners of the field; we do not provide an equilibrium logic for their existence but instead explore their implications for industry structure. Nevertheless, we think that this approach is necessary and useful. First, many of the sweeping changes in regulations and information technology, which many think will fundamentally alter the nature of the financial services industry, can only be evaluated with models that work out their industry-level implications. In turn, to do such an analysis it is necessary to identify whether and how these changes interact and affect the fundamental economics of the technology. Second,

\footnotetext{
${ }^{6}$ In other words, by "technology" we mean the shape of the production function.
} 
many of the policy questions that these changes motivate, such as their effect on concentration or their antitrust implications, are about industry structure. Third, policy interventions must by necessity be aimed at industry-level variables and cannot hope to be tailor-made to each particular detail.

The rest of the paper proceeds as follows. In section 2 we take a look at the economics and the technology of relationships. Section 3 characterizes the structure of the investment banking industry. Section 4 discusses some policy implications of the analysis. Section 5 presents some concluding remarks.

\section{How are relationships produced?}

In this section we briefly present evidence on the importance of relationships in investment banking and then discuss the economics of the technology of relationships.

\subsection{The Importance of Relationships in Investment Banking}

The literature sharply distinguishes between bank- and market-based financial systems. On the one hand, in bank-based systems intermediaries establish long-term relationships with firms and keep loans in their balance sheets. On the other hand, in market-based systems firms sell their security directly to investors (in 'direct' markets business firms are supposed to meet face to face with investors), who form portfolios to diversify risks. Nevertheless, while this distinction is useful to help thinking about striking cross-country differences among financial systems (see, for example, Allen and Gale [1995 and 2000]), it obscures the fact that in developed security markets firms sell their security through investment banks with whom they establish long-term relationships.

This is well documented for the US. market, the paradigmatic market-based system. ${ }^{7}$ Until about 25 years ago the rule in the industry was that a firm would maintain relationships with only one investment bank. This has changed in the recent past, but it is still the case that firms establish long-term relationships. ${ }^{8}$ For example, Baker (1990) examined ties between investment banks and corporations with market value of more than $\$ 50$ million between 1981 and 1985 . He reports that the 1091 corporations that made two or more deals during this period used three lead banks on average (these firms made eight deals on average). All but nine granted more than 50 per cent of their business to their top three banks and, on average, 59 per cent of the business was allocated to the top bank. Similarly, Eccles and Crane (1988, ch. 4) report that among the 500 most active corporations in the market between 1984 and 1986, 55.6 per cent used predominantly one bank to float their security, and the rest maintained relationships with only a few banks. They did not

\footnotetext{
${ }^{7}$ See Wilhelm and Downing (forthcoming) for an overview.

${ }^{8}$ See Nanda and Warther (1998) for an analysis of the trends in the strength of underwriting relationships.
} 
find any corporation selecting underwriters on a deal-by-deal basis. James (1992) finds that in the first common stock security offering after an IPO, 72 per cent of firms choose the same lead bank as before; for debt offerings, 65 per cent of issuers do not switch banks. Similarly, Krigman et al. (2001) show that 69 per cent of firms that did an IPO between 1993 and 1995, and a seasoned equity offering (SEO) within three years of the IPO, chose the same lead underwriter.

Why should we care about long-term relationships? A large literature argues that relationships facilitate monitoring and screening and can overcome the problems created by asymmetric information. ${ }^{9}$ As Boot (2000) argues, in a relationship the bank invests in obtaining firm-specific information, which is often proprietary in nature, and evaluates the profitability of these investments through multiple interactions with the same customer over time or across products. Thus, the benefits of relationships stem from the investment bank making decisions based on better information than what is publicly available.

Booth and Smith (1986) argue that underwriters certify that the valuation of the security made by the firm is appropriate. In so doing, they increase the net flow of capital to issuing firms and, moreover, ensure that on average higher quality firms get funding. If so, then security markets with an established investment banking industry should perform better. For example, Ljungqvist et al. (2001) examine 2,143 IPOs by issuers in 65 countries outside the United States between 1992 and 1999. They find that firms selling their securities to US. investors through US. banks typically charge higher direct fees, but including underpricing they are considerably cheaper. ${ }^{10}$ They argue (p.25) that "[...] the more sophisticated capital markets outside the US. have only recently begun to develop[... the relationships that link key intermediaries in the venture capital and the private equity markets to the primary and secondary markets."

It has been argued that relationships with commercial banks have the drawback of introducing a soft budget constraint, because banks cannot credibly commit to withdraw credit when the borrower is in financial trouble, and this worsens ex ante incentives (see Bolton and Scharfstein [1996] and Dewatripont and Maskin [1995]). An investment bank avoids this problem, because typically it does not maintain the firm's security in its balance sheet, but sells it to investors. It has also been argued that relationships may subject the firm to a hold up from the commercial bank with whom it has a relationship. As we will see now, however, in the case of investment banks the opposite seems to be more relevant: firms may find it too easy to switch investment banks once they have established the relationship.

\footnotetext{
${ }^{9}$ See Boot (2000) for a survey.

${ }^{10}$ Ljungqvist et al. (2001) estimate that $73 \%$ firms that sold to US. investors through US. banks would have been made worse off by switching to "cheaper" (i.e. lower fees) alternatives once the higher underpricing spreads are considered, thus resulting in a median reduction in net proceeds of US $\$ 11.7$ million. (Note that the mean gross proceeds in their sample is US\$33 million [median: US\$ 157 million].
} 


\subsection{The Economics of Investment Banking Relationships}

The technology of relationships has three important characteristics: sunk set up costs, loose linkages, and nonexcludability. We discuss and motivate each in turn. ${ }^{11}$

First, firm-bank relationships are long term and there is evidence that investment banks have to incur sunk costs to set them up and acquire information. For example, James (1992) presents evidence suggesting that the information gathered by an investment bank for one deal can be reused in future deals. Moreover, a significant fraction of these sunk costs is incurred by the investment bank. This occurs because most of the exchange of information takes place through direct interaction with the bank's staff.

Second, firms and investment banks interact constantly, but the bank is paid only when a deal is made. Eccles and Crane (1988) call this the 'loose linkage' between costs and fees. It implies that investment banks recover sunk relationship costs only if selected to do a deal. ${ }^{12}$ Why loose linkage? We will not provide a model that explains why investment banks are not paid fees just for establishing and maintaining relationships. But it is commonly argued that it is difficult for business firms to evaluate the quality of the advice provided, unless a deal is made (see Eccles and Crane [1988]).

Third, to a significant degree investment banks cannot establish property rights over the information gathered in a long-term relationship-i.e. information is nonexcludable. ${ }^{13}$ This is so for three reasons. First, as said, most of the exchange of information takes place through direct interaction between the firm and the investment bank's staff. The relationship-specific knowledge leaves with employees when they are hired away. ${ }^{14}$ For example, Deutsche Bank built a global investment bank in a year (Deutsche Morgan Grenfell) by hiring away staff en masse from other major banks. The second reason is that ideas and products can be copied. ${ }^{15}$ Last, in many cases relationships are not exclusive (see Eccles and Crane [1988]).

\subsection{A Simple Model of Relationships}

One can model this technology assuming that an investment bank must incur a sunk cost $R$ to do the deals of a firm. This cost is sunk because once $R$ is incurred the bank can do any number

\footnotetext{
${ }^{11}$ See Anand and Galetovic (2000a, 2000b) for a more detailed discussion.

${ }^{12}$ The extreme case of lose linkage is analysis, where banks earn most of their commissions from investors who trade the firm's security.

${ }^{13} \mathrm{~A}$ good or service is excludable if the owner can prevent others from using it at a very low cost.

${ }^{14}$ See Anand and Galetovic (2000a).

${ }^{15}$ Tufano (1989) estimates the costs of designing a security, including product development, marketing and legal expenses to be between $\$ 0,5$ million and $\$ 5$ million. These products cannot be patented and all details become publicly available once the offering is filed with the SEC. For a model of product innovation in investment banking, see also Bhattacharya and Nanda (2000).
} 
of deals with the same firm at no additional cost. Nevertheless, this cost is also nonexcludable: once incurred, all investment banks can do deals with the firm without incurring any costs. (To keep things as simple as possible, most assumptions are extreme; but, as we show in Anand and Galetovic [2001], these assumptions entail no loss of generality.) When a bank does a deal (but only then) it charges a commission proportional to the size of the deal; this is loose linkage. Call this proportional fee $\lambda$, with $0 \leq \lambda \leq 1$.

Now consider a very simple one-period game. Each firm establishes a relationship with one investment bank (in Anand and Galetovic [2001] we generalize this to multiple relationships). After investment banks incur $R$, they set fees $\lambda$ and deals are implemented.

The reader probably knows already what the equilibrium of this game looks like. Nonexcludability implies that any investment bank can do the firm's deal at a cost considerably less than $R$ after relationships have been established. Hence, in a one-period game all find it profitable to free ride on the effort and expense of others and the equilibrium fee will be driven well below what is necessary to recover the sunk relationship cost $R$; in fact, in this example Bertrand competition drives fees to zero. Loose linkage, in turn, implies that investment banks do not charge for establishing relationships. Anticipating all this, no investment bank will establish a relationship in the first place.

The previous result illustrates the well-known tension between competition and relationships. As Aoki and Dinc (1997) point out, financiers will establish relationships only if they expect to obtain long-term rents that cover the sunk investment cost. But intense price competition is deleterious to long-term rents. Hence, one will not have relationships unless competition is imperfect.

Among the mechanisms that can restrain price competition are regulations, ${ }^{16}$ frictions like informational monopolies, ${ }^{17}$ and contracts. ${ }^{18}$ Nevertheless, the investment banking industry tends to be quite unregulated, informational monopolies are unlikely because nonexcludability and loose linkage suggests that contracts for bonding firms to investment banks are almost nonexistent. What remains is voluntary 'cooperation' among investment banks not to undercut each other. In fact, the industry is notorious for soft price competition. For example, Matthews (1994 p. 161) notes that spreads on high-quality, long-term corporate bonds have been for many decades $7 / 8$ per cent of capital raised. Similarly, in England, for several decades underwriting fees have been 1.25 per cent of the capital raised. ${ }^{19}$ And recently, Chen and Ritter (2000) document the remarkable clustering of IPO spreads at seven percent. ${ }^{20}$ In the next section we will present a simple model of the

\footnotetext{
${ }^{16}$ See, for example, Hellmann et al. (1997).

${ }^{17}$ See Besanko and Thakor (1983), Boot and Thakor (2000), Fischer (1990), Rajan (1992) and Sharpe (1990).

${ }^{18}$ See Aoki and Dinc (1997, s.3) for a discussion of these mechanisms.

${ }^{19}$ See "Some Old Peculiar Practices in the City of London," The Economist (February 18, 1995).

${ }^{20}$ See also "Overcharging Underwriters" The Economist (June 27, 1998), where it is noted that "... studies in both countries suggest issuing companies are overcharged, and that they are stung for more in America." Similar
} 
investment banking industry that shows how voluntary cooperation among investment banks can emerge, which in turn sustains relationships.

\section{Relationships and the structure of the investment banking industry}

To establish relationships, cooperation among investment banks must be self enforcing: that is, it must be in each bank's self interest not to undercut its rivals, despite that in the short run it is profitable to do it. It seems that investment banks manage to restrain price competition in some markets. But how do they do it? As is well known, cooperation is in principle possible when agents repeatedly interact. This suggests that the appropriate setting to explain relationships is a repeated game among investment banks. In this section we show how repeated interaction can indeed lead to an equilibrium where relationships are established. What is a bit more surprising, however, is that sunk relationship costs, loose linkage and non excludability impose quite strong restrictions on aggregate market structure. These restrictions materialize in three key conditions, which can be used to characterize industry structure and interpret several facts of the industry, and systematically explore the consequences of policy-induced changes.

\subsection{The Implicit Cooperation Condition and Industry Structure}

Consider a repeated game where investment banks live indefinitely and play the one-period game we sketched in the previous section over and over again. They discount the future, so that one dollar at the beginning of next period is worth only $\delta$ dollars today, with $0<\delta<1$. Suppose also that each investment bank must pay a one-time sunk entry cost $\mathcal{E}$ to enter the industry and let $\lambda^{(c)}$ be the proportional fee charged by investment banks in equilibrium (the superscript ' $c$ ' stands for cooperation). What are the conditions under which investment banks cooperate?

Relationships can be sustained when the long-run profits that each bank expects to make from continued cooperation are greater than the short-run profits that can be made by undercutting and free riding on rival's efforts. Long-run profits are obtained as follows. Suppose that all banks cooperate forever. If the volume of deals made by a firm is $V$ on average (more on the determination of $V$ later), then each firm leaves a surplus $\lambda^{(c)} V-R$. With $f^{(r)}$ firms that establish relationships in the whole market, and a market share $\eta_{i}$, then the present value of continued cooperation for bank $i$ is

$$
\frac{1}{1-\delta} \eta_{i} f^{(r)}\left(\lambda^{(c)} V-R\right)
$$

Now we obtain the value of undercutting. Note that when bank $i$ undercuts by offering a shade

attributions to bankers can be found elsewhere, as noted by Chen and Ritter (2000, p. 1,106). For an empirical analysis of the IPO market see Hansen (2001). 
below $\lambda^{(c)}$ it will attract business from all firms for one time, increasing its market share from $\eta_{i}$ to 1. It is costless for bank $i$ to do additional $\left(1-\eta_{i}\right) f^{(r)}$ deals; this is nonexcludability. Assuming that deviators destroy cooperation forever (that is, after deviations investment banks never cooperate $\operatorname{again}^{21}$ ), the one-time gains of undercutting are

$$
\left(1-\eta_{i}\right) f^{(r)} \lambda^{(c)} V
$$

Thus, relationships will be sustainable if for all banks,

$$
\frac{\delta}{1-\delta} \eta_{i} f^{(r)}\left(\lambda^{(c)} V-R\right) \geq\left(1-\eta_{i}\right) f^{(r)} \lambda^{(c)} V
$$

(the present value of continued cooperation is discounted because the decision not to undercut is made after relationship costs have been incurred).

The cooperation condition (3.1) tells several things about the investment banking industry. First, since $\left(1-\eta_{i}\right) f^{(r)} \lambda^{(c)} V>0$, it follows that $\lambda^{(c)} V-R>0$; fees paid by a firm cover more than the relationship cost. These rents are not the whole story as far as investment bank's profits are concerned (recall the entry cost $\mathcal{E}$; see below), but they cannot be eliminated through competition. The reasons that any bank can always make profits by undercutting. Hence, if $\lambda^{(c)} V-R=0$, all would like to undercut and there would be no incentives to establish relationships. ${ }^{22}$ All this, again, is the consequence of nonexcludability- $R$ does not appear on the right hand side of the cooperation condition (3.1).

The second implication is that investment banks will neither be too small nor too large. On the one hand, if $\eta_{i}$ is too small, then undercutting becomes more attractive than cooperating and relationships cannot survive. On the other hand, if one investment bank becomes very large, it will be happy too cooperate. But since market shares add up to 1, the rest will be too small, and they will find it more profitable to undercut. All in all, condition (3.1) says that there is room only for a few large investment banks of not-too-different sizes. In fact, by letting all market shares be the same (i.e. the case in which each investment bank grabs a fraction $\frac{1}{m}$ of all relationships) one obtains an upper bound on the number of investment banks that can participate in the industry, call it $m^{(c)}$. After some minor algebra, one can show that this upper bound satisfies

$$
\frac{\delta}{1-\delta} f^{(r)}\left(\lambda^{(c)} V-R\right)=\left(m^{(c)}-1\right) f^{(r)} \lambda^{(c)} V
$$

\footnotetext{
${ }^{21}$ That is, we use a trigger strategy here where one deviation reverts the game to the equilibrium of the one-period game. In a precise sense there is no loss of generality in assuming this extreme punishment for deviations. See Anand and Galetovic (2000a, section IIIC).

${ }^{22}$ For example, Chen and Ritter (2000) argue that spreads in IPOs are above competitive levels. For a different interpretation, see Hansen (2001).
} 
Note that an upper bound on the number of investment banks implies a lower bound on concentration. Hence, condition (3.2) suggests that investment banking is a natural oligopoly.

The third implication is that the lower bound on concentration is independent of the size of the industry. As is usually argued, a larger market increases the attractiveness of undercutting. But, on the other hand, in a larger market cooperation is also more attractive. In this model both effects cancel out exactly, because, $f^{(r)}$, the number of firms that establish relationships and a measure of industry size, multiplies both sides of the cooperation condition (3.1). One implication of all this is that once an investment banking industry exists, its structure should not change with the size of the market. This is a central prediction of the model and quite different from standard IO models, which predict that concentration should fall with market size as entry costs and scale economies become less important. Below (see section 4.3) we will discuss some quite striking predictions that this result has on how the global investment banking industry should evolve.

Do these predictions square with the facts? Figure 1 plots the market share of the top- 8 US. banks in underwriting between 1950 and 1986 at intervals of five years (left-hand side) and the volume of securities underwritten during the same period (right-hand side). Figure 2 does the same for M\&A's, but the period is 1987-1998. Both figures tell essentially the same story: the industry is quite concentrated, concentration is stable over time, and it does not show any systematic relation with volume. Volume in underwriting increases more than 80 times, yet market structure remains the same. Similarly in M\&As where volume increases about 12 times.

Table 1a shows market shares in underwriting in 1999 according to the size of issues (all credit is assigned to the underwriter that leads the syndicate), and Table $1 \mathrm{~b}$ does the same according to fee income (these are fees actually cashed by the underwriter). While volumes are much higher than in 1986, the share of the top 8 underwriters remains above 70 per cent. More remarkably, as predicted by the model, there is no dominant investment bank-the largest has a share of slightly more than 15 per cent. This pattern is similar for other investment banking markets (see, for example, Santomero and Babbel [2001, ch.21]).

In the United States there are many small investment banks beyond the few large, more prestigious or 'bulge bracket' banks that appear in the charts and tables (in fact, according to the Bankscope data base there are presently 1,138 investment banks and security houses in the United States). Since it is a well known fact that in many industries the size distribution of business firms is highly skewed (what is known as Gibrat's law), one could argue that these fringe banks compete with the large banks thus moderating their market power but also eroding the incentives to establish relationships in the first place. In the next subsection, however, we will argue that these small banks can and probably should be ignored when studying relationships.

The second objection is that investment banks are multiproduct firms, so that concentration in any one market may mask that leading banks differ across products. Nevertheless, the top, 
bulge bracket banks tend to be the same in most product lines (see, for example, Santomero and Babbel [2001, p.500]. Moreover, as we show in our (2000b) paper, as long as the economics of the technology exhibits these characteristics in some segments of the investment banking industry, then the cooperation condition (3.1) must hold across products. In particular, this implies that nonprice competition cannot dissipate rents-otherwise cooperation would no longer be self-enforceable.

\subsection{Relationships are for Large Firms}

So far the focus has been on aggregate market structure. But sunk costs to establish relationships introduce scale economies at the level of each relationship (that is, at the local level), which suggests that relationships will not be worth their cost for low-volume firms.

To think about local market structure, assume that firms are of two types, high- and lowvolume. ${ }^{23}$ A high-volume firm generates a volume $v^{(h)}$ of deals, and a low-volume firm generates a volume $v^{(\ell)}$, with $v^{(\ell)}<\frac{R}{\lambda^{(c)}}<v^{(h)}$. A fraction $\zeta$ of firms is high-volume, and there are $f$ firms in total (clearly, $f \geq f^{(r)} 0$ ). Firms can do deals using an investment bank, in which case they do not incur in any transaction costs beyond the fee they have to pay. Alternatively, they can use some other means to do the deal, but this imposes a proportional transaction cost $\beta v$ on the firm. That is, the costs of the alternative increase proportionally with the size of the deal.

The "alternative" to establish a relationship could be many different things. For example, instead of issuing securities, the firm may borrow from a commercial bank or, instead of hiring investment banks, the firm may set up its own M\&A department. A particularly interesting interpretation, however, is that the firm may do deals through an investment bank but without establishing a long-term relationship. As mentioned before, in the United States there are many small investment banks who do deals on an arm's length basis.

Since the transaction cost of this alternative equals $\beta v$, it increases linearly with the size of the deal. There are two substantive implications for that technology. First, contrary to relationships, there are no economies of scale at the firm level-larger deals are more costly. One reason why it is reasonable to model this transaction cost as proportional is that the cost of mistakes (e.g. mispricing), which should occur with higher probability if the investment bank knows less about the firm, is roughly proportional to the size of the deal. Second, we have not specified who bears this cost. But, as long as there isn't a loose linkage, this is irrelevant because one way or the other the firm will bear the cost of the deal.

Now it is straightforward to note that

$$
\lambda^{(c)} v-R \geq 0
$$

\footnotetext{
${ }^{23}$ Again, no loss of generality here. In Anand and Galetovic (2000b) we work with a continuous distribution over volumes.
} 
is necessary for an investment bank to establish a relationship with a given firm (note that $v$ is the volume of a given firm, not average volume $V$; hence the weak inequality). Hence, firms with small $v$ s will not be chosen by investment banks. In our example, that is the case of low-volume firms, since $v^{(\ell)}<\frac{R}{\lambda^{(c)}}$ by assumption.

It may not come as a surprise that low-volume firms do not participate in the market, because it is well known that the average cost of issuing security falls with the size of the issue, and considerably so after issues surpass the $\$ 20$ million threshold (see Ritter [1987] and Lee et al. [1997]). Nevertheless, note that inequality (3.3) is not driven by the costs borne by the firm, but by the sunk costs of establishing a relationship, which are paid by the investment bank. Thus, the inequality says that investment banks will exclude low-volume firms, not that costs will make low-volume firms unwilling to establish relationships. Why? Note that $\lambda^{(c)} \leq \beta$. Hence no matter how small, a firm would always like to establish relationships. This is again loose linkage: fees do not depend on $R$. Therefore banks must decide who gets to establish relationships. ${ }^{24}$

Now interpret the alternative available to low-volume firms as a fringe of investment banks that do deals on an arm's length basis. The size of the relationship segment of the industry $(\zeta f$ in the model) is completely determined by condition (3.3), so that the market can be split in a relationship segment and an arm's length segment. A prediction that follows directly from condition (3.3) is that deals will be smaller on average in the arm's length segment.

In fact, there is evidence that this is so in practice. In Anand and Galetovic (2002), we report that each deal done by firms who did two or more M\&As between 1987 and 1998 is on average about three times larger than a deal made by a firm that did only one M\&A over the period. ${ }^{25}$ In the IPO market, Table 2, which is taken from Ritter (1987, p. 272), shows that best-effort contracts are predominant for firms with IPO proceeds of $\$ 2$ million or less, but almost nonexistent for IPOs with gross proceeds of $\$ 10$ million or more. ${ }^{26}$ By contrast, firm-commitment contracts are predominant for larger issues. In a best-effort contract the issuing firm and the investment bank agree on an offer price and a minimum and maximum number of shares to be sold. Then the investment bank makes its 'best effort' to sell the shares to investors. In a firm-commitment contract the investment bank guarantees the firm a given proceed from the issue after the final prospectus is issued, whether or not the issue is fully subscribed at the offer price (see Ritter [1987]). As Ritter points out, a firmcommitment offer involves relatively more certification than a best-effort offer, which is consistent with the fact that the major bracket investment bankers almost always do firm commitment offers.

\footnotetext{
${ }^{24}$ For the case of IPOs, Chen and Ritter $(2000$, p. 1,114) argue that the conventional wisdom is that the costs of large, prestigious investment banking houses are so high that they do not find it profitable to do small deals.

${ }^{25}$ Of course, both averages include only acquirors, not targets.

${ }^{26}$ In a best-effort contract the issuing firm and the investment bank agree on an offer price and a minimum and maximum number of shares to be sold. Then the investment bank makes its 'best efforts' to sell the shares to investors. In a firm-commitment contract the investment bank guarantees the firm a given proceed from the issue after the final prospectus is issued, whether or not the issue is fully subscribed at the offer price. See Ritter (1987).
} 
Chen and Ritter $(2000$, p. 1,114) argue that prestigious investment banks have costs that are so high that they do not find it profitable to do small deals.

The second question is how arm's length investment banks affect competitive conditions in the relationship segment. A striking implication of rationing is that the answer is "not at all," because loose linkage implies that there is no price indifference condition that links both segmentsas said, given that $\lambda^{(c)} \leq \beta$, all firms, high- or low-volume would like to establish a relationship. This implies that one should speak of two separate industries: relationship investment banking, where a few large banks serve larger firms, and arm's-length investment banking, which is tailored to smaller firms. Note that this suggests that measures of industry concentration that merge both segments are misleading. If anything, the graphs and tables presented in the previous subsection understate concentration in the investment banking industry.

The separation of the industry in two segments suggested by the model is similar to the common distinction between 'bulge bracket' banks and the rest. In fact, an attribute that is measured and used in many empirical studies is the 'prestige' or reputation of the investment bank, and bulge bracket investment banks tend to be the more prestigious. ${ }^{27}$ Prestige and reputation serve useful purposes. For example, it is argued that when doing an IPO, investment banks with high reputation select firms with low dispersion of possible firm values. Moreover, in the IPO market there is evidence that investment banks with higher reputation underwrite issues that are initially underpriced less and that have higher returns in the long-run (see Carter et al. [1998] and Nanda et al. [1995]). Thus, the choice of underwriter works as a signal of firm quality. ${ }^{28}$ Our model suggests a possible foundation for prestige and better performance, namely that only a subset of investment banks establish long-term relationships. Now, if some services can only be provided through relationships, firms in the relationship segment get a different type of service than in the arm's length segment. And if the quality of the monitoring and information creation is substantially lower without them, then security markets without long-term relationships will be less effective in allocating resources to these firms.

The latter point leads to the third role of condition (3.3), to determine the size of the relationship segment. In our example, low-volume firms are excluded by investment banks, so that only $\zeta f$ firms (i.e. those that are large) are eligible for relationships and average volume is $v^{(\ell)}$. The size of the relevant market is therefore only $\zeta f$. Now if, as seems reasonable, deal volume is positively correlated with firm size, this suggests a link with the (physical) size-distribution of business firms. Ceteris paribus, the relevant market for relationship investment banking should be larger in countries where there are more large firms. It will be seen next that this imposes an endowment constraint on the existence of relationship investment banking: relationships cannot

\footnotetext{
${ }^{27}$ See Carter and Manaster (1990).

${ }^{28}$ See Titman and Trueman (1986).
} 
emerge if $\zeta f$ is too small, i.e. when large firms are few.

\subsection{When Will an Investment Banking Industry Emerge?}

An additional equilibrium constraint is that investment banks must make enough profit to cover the entry $\operatorname{cost} \mathcal{E}$. It will be shown in this subsection that the effect of entry costs is asymmetric: when the market is small (i.e. $f^{(r)}$ is small), entry costs are important and may even prevent the emergence of an investment banking industry. By contrast, when the market is sufficiently large, entry costs are irrelevant, and only the cooperation conditions (3.1) or (3.2) matter.

The present value of profits made by investment banks in a long-run equilibrium with relationships equals $\frac{1}{1-\delta} \frac{f^{(r)}}{m}\left(\lambda^{(c)} V-R\right)$ when all banks have the same market share. This present value must be enough to cover the entry cost $\mathcal{E}$. Hence

$$
\frac{1}{1-\delta} \frac{f^{(r)}}{m}\left(\lambda^{(c)} V-R\right) \geq \mathcal{E}
$$

is an additional constraint, which defines a second upper bound on the maximum number of banks in the market. This upper bound must satisfy

$$
\frac{1}{1-\delta} \frac{f^{(r)}}{m^{(z p)}}\left(\lambda^{(c)} V-R\right)=\mathcal{E}
$$

where $m^{(z p)}$ is the number of intermediaries consistent with zero long-run profits or a normal return on capital invested.

Note that, in contrast with the upper bound $m^{(c)}$ derived from the cooperation condition $(3.2), m^{(z p)}$ increases with the size of the relevant market $f^{(r)}$, because the entry cost $\mathcal{E}$ is spread among more relationships. Hence, when the market is sufficiently large, $m \leq m^{(c)}$ becomes the only relevant constraint; (3.4) always holds with slack and scale economies at the industry level are irrelevant as a determinant of market structure. ${ }^{29}$ More than that, because investment banks must make rents to preserve the incentives to establish relationships, and rents grow with market size, the industry will make profits that are higher than normal. Yet these supranormal profits will not attract further entry because when $m>m^{(c)}$ cooperation is no longer self enforceable. Hence, supranormal profits should survive in the long-run.

On the other hand, scale economies matter when the relevant market is small. To see this, let $\lambda^{(c)}=\beta, m=1$ and substitute in constraint (3.4). If

\footnotetext{
${ }^{29} \mathrm{It}$ is important to distinguish scale economies at the market level (this subsection) from scale economies that occur in each firm-bank relationship (the previous subsection). Relationship costs do not imply scale economies at the industry level, because duplicating the number of firms duplicates aggregate expenditures.
} 


$$
\frac{1}{1-\delta} f^{(r)}(\beta V-R)=\frac{1}{1-\delta} \zeta f\left(\beta v^{(h)}-R\right)<\mathcal{E}
$$

then an investment banking industry cannot emerge, because it would lose money. Inequality (3.6) also shows that a "small" market may mean that the economy is small and there are few firms (a small $f$ ), or, rather, that few firms are high-volume (a small $\zeta$ ). Thus, provided that volumes increase with (physical) firm size, being endowed with enough large firms is key for relationship investment banking to emerge. While policy can affect the number of high-volume firms (see the next section), the size-distribution of business firms depends heavily on the structural characteristics of the economy. It is in that sense that one can speak of the size distribution of firms as a structural determinant of the feasibility of relationship investment banking. Countries in which large firms are few cannot have domestic relationship investment banking. This constraint is irrelevant in an economy like the United States, but is probably important in many developing countries.

\section{Some policy implications}

In this section we use our model to discuss some policy implications of the model.

\subsection{Can Policy do Anything to Foster Relationships and Investment Banking?}

If relationships are necessary for effective security markets, then developing an investment banking industry should be a priority. But, can policy do anything to foster domestic relationship investment banking? Since an investment banking industry can emerge only if

$$
\frac{1}{1-\delta} \zeta f\left(\beta v^{(h)}-R\right) \geq \mathcal{E}
$$

it may seem natural to start by looking at policies that affect entry $\operatorname{costs} \mathcal{E}$. For example, regulations that restrict the entry of foreign investment banks into the domestic market, or prevent commercial banks from doing investment banking activities, are likely to increase the costs of entry and make it less likely that a domestic investment banking industry emerges.

Yet the model suggests that industry-level variables may not be the only relevant ones. The left-hand side of condition (4.1) indicates that whether an investment banking industry can emerge also depends on local-level variables (in particular volume and relationship costs), and, especially $\zeta f$, the number of firms that satisfy condition (3.3), which we reproduce here:

$$
\lambda^{(c)} v-R \geq 0
$$

There are some "obvious" policies that affect $\zeta f$ for a given size-distribution of business 
firms. To begin with, regulations that protect the interests of minority investors and strengthen shareholder and creditor rights will make investors more willing to buy security from a given firm. Furthermore, good accounting standards and rules that force firms to disclose information lower the costs of information and establishing relationships. Clearly, these regulations by themselves foster better functioning security markets. Nevertheless, condition (4.1) suggests a threshold effect: by increasing the number $\zeta f$ of firms that meet condition (3.3), these "obvious" policies make it more likely that long-term relationships and an investment banking industry become profitable. When this occurs, the quality of the security market improves even further.

A developed commercial banking sector will probably reduce $R$. Many empirical studies suggest that the information created by commercial banks affects prices in security markets, which suggests that investment banks can benefit from the information created by commercial banks. ${ }^{30,31}$ Relatedly, one could argue that universal banking fosters security market development, because these banks can exploit economies of scope thus reducing $R$. Gande et al. (1997) examined debt security underwritten by subsidiaries of bank holding companies in the United States and found evidence that between January 1993 and March 1995 commercial banks brought a relatively larger proportion of small issues into the market. While 31 per cent of commercial bank underwritings are of smaller issues (less than $\$ 75$ million in size) only 8 per cent of issues underwritten by investment banks are of smaller issues (see also Gande et al. [1999]). ${ }^{32}$

All said, however, as we discussed in the previous section, the size-distribution of business firms imposes a structural constraint. If $\zeta f$ is small because there are few large firms, then policy cannot do much against it as long as the economy remains small; then relationships and an investment banking industry will not emerge, and policy can do little about it. Since relationships make a difference in overcoming the problems created by asymmetric information, one should expect less effective and less developed security markets in these countries.

Large firms in a small economy need not be excluded from developed security markets, because conditional on being in a security market with an investment banking industry, a firm needs only to satisfy condition (3.3) to establish a relationship. Thus, large firms that are allowed to list in foreign developed markets should be able to realize the benefits of relationships. This suggests

\footnotetext{
${ }^{30}$ See, for example, James (1987), Lummer and McConnel (1989), and Shockley and Thakor (1997).

${ }^{31}$ Incidentally, this could be behind the complementarity of commercial banking and security market development that has been detected in studies of security market development and growth. See Levine and Zervos (1998).

${ }^{32}$ Many authors have pointed out that commercial banks may want to misrepresent the value of the issued securities when proceeds are used to refinance loans (see Saunders [1985], Walter [1985], Benston [1990], and Saunders and Walter [1994]). But, on the other hand, commercial banks have access to proprietary information. See Puri (1999) for a model of this trade off. Ang and Richardson (1994), Kroszner and Rajan (1994), and Puri (1994) found that securities underwritten by commercial banks before Glass-Steagall had a better default record than securities underwritten by investment banks. Gande et al. (1997) find that yield spreads for lower credit rated issues (Caa$\mathrm{Ba} 3)$ are 27 basis points smaller when the bank holds a significant lending stake, which is evidence against the conflict-of-interest view.
} 
the following: in economies where condition (4.1) is not met because $\zeta f$ is small a liberalization policy that allows foreign capital to enter the domestic security market may be far less effective than one which allows domestic firms to access foreign capital by listing in foreign security markets.

\subsection{Vertical Segmentation and Investment Banking in Emerging Markets}

Our analysis suggests that the investment banking industry is vertically segmented: when available, only large firms have access to relationships and smaller firms must do their business on an armslength basis. As said before, this pattern is clearly present in the United States, where large firms establish relationships with bulge-bracket banks and smaller firms do business with a large number of small "fringe" banks. In some emerging markets a similar pattern has tended to emerge. According to Khanna and Palepu (2001), in emerging economies only large business group tend to establish relationships with multinational intermediaries. Non-group firms tend to be smaller and their volume of deals is insufficient to warrant a relationship with a multinational intermediary. More generally, one should expect that large investment banks who set shop in an emerging market to specialize in large firms. Smaller firms who make it to the stock market will probably not benefit much from their presence and will be served by local arms length investment banks.

\subsection{Do Foreign Listings Hurt Local Security Markets?}

In recent years many firms from emerging economies have listed their securities on international exchanges, which is part of a global trend of increased capital flows, tighter financial links and greater presence of global financial firms (see Claessens et al. [2001]). For example, Claessens et al. (2001, p. 27) report that the ratio of capital raised abroad to capital raised domestically by firms in middle-income economies has increased substantially reaching almost 3.5 in 2000. Many observers see the migration of domestic firms to foreign markets as a mixed blessing: on the one hand, there is evidence that companies who list abroad obtain better conditions and lower their cost of capital; on the other hand, migration seems to reduce trading in the local market and hurt companies that cannot list abroad. In fact, Moel (2001) reports that the issuance of ADRs seems to negatively affect liquidity and growth of the securities of firms that are listed only in the domestic market. ${ }^{33}$

Why does migration to foreign security markets negatively affect the firms that only remain listed locally? One explanation (see, for example, Rigobon [2001]) is that there is a flight-to-quality effect, since only the good firms can issue ADRs; once they do, firms that do not leave are revealed as bad. The shortcoming of this explanation, however, is that firms that issue ADRs are usually large relative to the firms that remain, which is observable ex ante. Our model, on the other hand,

\footnotetext{
${ }^{33}$ For example, he finds that a one percentage point increase in the fraction of firms listed with ADRs leads to a $9 \%$ decrease in turnover of the shares of firms that do not issue ADRs (evaluated ate the sample mean).
} 
suggests an alternative reason why ADRs may hurt the local market-fixed costs. After large many firms leave to list abroad the relevant market for investment banking activities - e.g. underwriting, analyst following, IPOs - shrinks and this induces exit from the industry. If intermediaries are necessary for security markets to work, one should expect that some of the firms that remain are hurt.

\subsection{What Will the Global Investment Banking Industry Look Like?}

Deregulation has allowed many investment banks to set foot in foreign markets, both through acquisitions and foreign subsidiaries. Moreover, there is considerable uncertainty on the future evolution of the European financial services industry. Will global competition, as some observers predict, lead to a unified global investment banking market with only a few megabanks? ${ }^{34}$ Our model suggests that the answer is not straightforward.

Consider, first, changes in regulation that allow or make it easier for foreign investment banks to enter a domestic market. Since "global" banks typically specialize in relationships, the logic of the cooperation condition (3.1) applies. This condition implies that there is room for at most a few investment banks in each relevant market. If entry by some foreign banks is successful, it necessarily implies that some domestic banks must exit; otherwise the incentives to maintain relationships cannot be preserved. Thus, when foreign banks enter into an established domestic market, one should expect changes in the identities of players, but not substantial consolidation.

A second set of regulatory changes affect firms rather than banks. Consider the relaxation of restrictions on foreign listings. This enlarges the relevant market that serves large firms from the national to the international level (e.g. one common European market, or Asian and Latin American firms floating their security in New York). For investment banks, this increases the size of the market. Recall, however, that industry structure is independent of industry size because both the value of cooperation and of cheating increase with market size. It follows that liberalization of listing requirements should lead to massive consolidation of investment banking at the global level.

A third implication of the model is that neither liberalization of entry requirements nor listing requirements for firms in foreign markets should change the dual market structure of investment banking. The reason is that fringe banks specialize in serving small firms which generate too little volume to justify establishing relationships and global banks tend to specialize in relationships. Hence, low-volume firms and fringe banks should not be affected much by what happens in the relationship segment, at which most regulatory changes are aimed.

\footnotetext{
${ }^{34}$ See, for example, The Economist: "The Doomed and the Dangerous" (December 5, 1998), "Investment Banking Boutiques: Small Fried" (June 8, 1996); and "The Last of the Mohicans" (July 20, 1996).
} 


\subsection{Antitrust Dilemmas in the Investment Banking Industry}

Ever since the Pujo hearings in the early twentieth century, the US investment banking industry has been constantly in the eye of antitrust authorities. ${ }^{35}$ Fixed and apparently high fees, and the existence of a few dominant banks whose market shares appear not to have changed much in spite of a tenfold growth in market size, concern some observers. Our model suggests, however, that the adequate competition policy in this industry is not straightforward.

Consider first the usual conjecture that soft price competition is an indication of a welfaredecreasing exercise of market power. We have seen that nonexcludability implies that pricing in this industry leads and that investment banks will probably earn excess rents. Moreover, our analysis suggests that banks price strategically and "collude" to maintain fees above average costs. But, as seen, soft price competition is necessary to support efficient, relationship-based production technologies. And banks must make profits even after covering their sunk costs of relationships, otherwise the price norm will not be self-enforcing. Thus, excess profits by banks are not sufficient evidence of welfare-decreasing anti-competitive behavior.

Next, consider the definition of the relevant investment banking market, which is central in antitrust analysis. A common argument is that the large number of small investment banks in the United States (about 1,100) imposes some competitive discipline on the pricing of large, bulgebracket banks. Our analysis suggests that this view may be wrong. Bulge-bracket banks differ from small ones in that they use a relationship-based technology for doing deals. One consequence is that the size of clients served by each segment will be different. Next, differences in bank profits and fees between the two segments will not be eliminated, even with costless entry and exit. Thus, changes in one segment of the market will have no effect on the nature of competition in the other segment. The key point is that, from a firm's perspective, relationship and arm's-length technologies are not substitutes at the margin and low volume firms are rationed out of relationships. For this same reason, Herfindahl indices may also be misleading indicators of industry concentration.

Third, note that the investment banking industry is naturally concentrated and condition (4.1) suggests that this should be even more so in economies with few large firms. Nevertheless, for economies with small markets allowing domestic firms to list abroad seems to be an obvious pro competitive policy which does not harm relationships.

All this is not to suggest that market power by itself is a good thing. As a policy to develop the investment banking industry, it would be clearly wrong to advocate regulations that restrict competition or facilitate market power exploitation. Nevertheless, our analysis does suggest that antitrust analysis of this industry is not straightforward and that market power is necessary for

\footnotetext{
${ }^{35}$ See Carosso (1970) for a comprehensive account of the Pujo hearings and the antitrust case against the investment banking industry that began in the late 1940s.
} 
relationships to exist.

\section{Conclusions}

The arguments made in this paper are built on the premise that resources are allocated better in security markets where firms and investment banks establish long-term relationships. This is consistent with the observation that long-term relationships between investment banks and firms are one of the hallmarks of developed security markets. We have shown how the industrial organization of investment banking is determined by the technology of relationships-sunk costs to establish a relationship, loose linkages and nonexcludability. If relationship banking and relationships lead to more effective security markets, how can policy foster them?

Our conclusions are somewhat mixed. On the one hand, there may be room in many countries to remove regulations that increase the costs of establishing and keeping relationships. These policies must not be aimed exclusively at industry-level variables like entry costs, but also at local level variables such as the cost of establishing a firm-investment bank relationship. But, on the other hand, we identified a fundamental "endowment" constraint that may constrain the development of an investment banking industry-the size-distribution of business firms. Because relationships with low-volume firms are not worth their cost, there is not much that policy can (or should) do when most firms in a given country are small. In such an economy "finance can't follow industry": our model suggests that a domestic investment banking industry cannot develop as long as firms remain small. If the information that is created in relationships is necessary to achieve better monitoring and screening and to overcome the problems created by asymmetric information, security markets will be less effective in these countries.

Nevertheless, lack of a domestic investment banking industry need not prevent domestic firms that are large enough from getting access to security market finance, provided that they are allowed to list abroad. By contrast, a liberalization policy that opens domestic markets to foreign capital and intermediaries is probably far less effective when there are only a few large firms to begin with. The implication is that when (domestic investment banking) finance can't follow industry, then countries should let industry follow (foreign investment banking) finance.

If restrictions on foreign listings are substantially lifted, what will a global investment banking market look like? We predict substantial worldwide consolidation. A few megabanks will do a significant fraction of the deals. They will enjoy some market power and returns above normal, but these imperfections are probably necessary for such an industry to exist. 


\section{References}

[1] Allen, F. and D. Gale, "A Welfare Comparison of Intermediaries and Financial Markets in Germany and the US.," European Economic Review 39, 179-209, 1995

[2] Allen, F. and D. Gale, Comparing Financial Systems. Cambridge: MIT Press, 2000

[3] Anand, B. and A. Galetovic, "Information, Nonexcludability and Financial Market Structure," Journal of Business 73, 357-402, 2000

[4] Anand, B. and A. Galetovic, "Does Compeition Kill Relationships? Inside Investment Banking," CEA Working Paper \#119, 2001

[5] Anand, A. and A. Galetovic, "Investment Banking Structure: Evidence from M\&As," work in progress, 2002

[6] Ang, J. and T. Richardson, "The Underwriting Experiences of Commercial Bank Affiliates Prior to the Glass Steagall Act: A Re-examination of Evidence for Passage of the Act," Journal of Banking and Finance 18, 351-395, 1994

[7] Aoki, M. and S. Dinc, "Relational Financing as an Institution and its Viability under Competition," CEPR publication $\mathrm{N}^{\circ} 488,1997$

[8] Baker, W., "Market Networks and Corporate Behavior," American Journal of Sociology 96, 589-625, 1990

[9] Benston,G., The Separation of Commercial and Investment Banking. New York: Oxford University Press, 1990

[10] Besanko, D. and A. Thakor, "Relationship Banking, Deposit Insurance and Bank Portfolio Choice." In C. Mayer and X. Vives (eds.) Capital Markets and Financial Intermediation. New York: Cambridge University Press, 1993

[11] Bhattacharya, S. and V. Nanda, "Client Discretion, Switching Costs, and Financial Innovation," Review of Financial Studies 13, 1101-1127, 2000

[12] Bolton, P. and D. Scharfstein, "Optimal Debt Structure and the Number of Creditors" Journal of Political Economy 104, 1-25, 1996

[13] Boot, A., "Relationship Banking: What do we Know?", Journal of Financial Intermediation 9, 7-25, 2000

[14] Boot, A. and A. Thakor, "Can Relationship Banking Survive Competition?", Journal of Finance 55, $679-713,2000$

[15] Booth, J. and R. Smith, "Capital Raising, Underwriting and the Certification Hypothesis," Journal of Financial Economics 15, 261-281, 1986

[16] Carosso, V., Investment Banking in America. Cambridge: Harvard University Press, 1970

[17] Carter, R., F. Dark and A. Singh, "Underwriter Reputation, Initial Returns, and the Long-Run of IPO Stocks," Journal of Finance 53, 285-311

[18] Carter, R. and S. Manaster, "Initial Public Offerings and Underwriter Reputation," Journal of Finance 45, 1045-1067, 1990

[19] Chen, H. and J. Ritter, "The Seven Percent Solution," Journal of Finance 55, 1105-1131, 2000

[20] Claassens, S., D. Kligebiel and S. Schmukler, "Explaining the Migration of Stocks from Exchanges in Emerging Markets to International Centers," mimeo, The World Bank, 2002 
[21] Dewatripont, M. and E. Maskin, "Credit and Efficiency in Centralized and Decentralized Economies", Review of Economic Studies 62, 541-555, 1995

[22] Eccles, R. and R. Crane, Doing Deals: Investment Banks at Work. Boston: Harvard Business School Press, 1988.

[23] Fischer, K., Hausbank Beziehungen als Instrument der Bindung zwischen Banken und Unternehmen. $\mathrm{PhD}$ Dissertation, University of Bonn, 1990

[24] Gande, A., M. Puri and A. Saunders, "Bank Entry, Competition, and the Market For Corporate security Underwriting," Journal of Financial Economics 54, 165-195, 1999

[25] Gande, A., M. Puri, A. Saunders and I. Walter, "Bank Underwriting of Debt security: Modern Evidence," Review of Financial Studies 10, 1175-1202, 1997

[26] Greenwood, J. and B. Jovanovic, "Financial Development, Growth and the Distribution of Income," Journal of Political Economy 98, 1076-1107, 1990

[27] Greenwood, J. and B. Smith, "Financial Markets in Development and the Development of Financial Markets," Journal of Economic Dynamics and Control 21, 145-181, 1997

[28] Hansen, R., "Do Investment Banks Compete in IPOs?: the Advent of the '7\% plus contract'," Journal of Financial Economics 59, 313-346, 2001

[29] Hayes S., M. Spence and D. Marks, Competition in the Investment Banking Industry. Cambridge: Harvard University Press, 1983

[30] Hellmann, T., R. Murdoch and J. Stiglitz, "Financial Restraint: Towards a New Paradigm," in M. Aoki, M. Kim and H. Okuno-Fujiwara (eds.) The Role of Government in East Asian Economic Development. New York: Oxford University Press, 1997

[31] James, C., "Some Evidence on the Uniqueness of Bank Loans," Journal of Financial Economics 19, 217-235, 1987

[32] James, C., "Relationship-Specific Assets and the Pricing of Underwriter Services," Journal of Finance 47, 1865-1885, 1992

[33] Khan, M. and A. Senhadji, "Financial Development and Economic Growth: An Overview, Working Paper, International Monetary Fund, 2001

[34] Khanna, T. and K. Palepu, "New Ventures in Emerging Markets," presentation at the David Rockefeller Center for International Studies and the HBS Latin American Research Center, 2001

[35] Krigman, L., W. Shaw and K. Womack, "Why do Firms Switch Underwriters?" forthcoming, Journal of Financial Economics, 2001

[36] Kroszner, R. and R. Rajan, "Is the Glass-Steagall Act Justified? A Study of the US Experience with Universal banking Before 1933," American Economic Review 84, 810-832, 1994

[37] Lee, I., S.Lochhead, J. Ritter and Q. Zhao, "The Costs of Raising Capital," Journal of Financial Research 19, 59-74,1996

[38] Levine, R, "Financial Intermediary Services and Growth," Journal of the Japanese and International Economy 6, 383-405, 1992

[39] Levine, R. and S. Zervos, "Stock Markets, Banks, and Economic Growth," American Economic Review 88, 537-558, 1998

[40] Ljungqvist, A., T. Jenkinson and W. Wilhelm Jr., "Global Integration in Primary Equity Markets: The Role of U.S. Banks and U.S. Investors," Review of Financial Studies, forthcoming, 2001 
[41] Lummer, S. and J. McConnel, "Further Evidence on the Bank Lending Process and the Capital Market Response to Bank Loan Agreements," Journal of Financial Economics 25, 99-122, 1989

[42] Matthews, J., Struggle and Survival on Wall Street. New York: Oxford University Press, 1994

[43] Moel, A., "The Role of American Depository Receipts in the Development of Emerging Markets," Economia 2, 209-273, 2001

[44] Nanda, V. and V. Warther, "The Price of Loyalty," manuscript, University of Chicago, Graduate School of Business, 1998

[45] Nanda, V., J. Yi and Y. Yun, "IPO Long-Run Performance and Underwriter Reputation," Working Paper, University of Michigan and University of Southern California, 1995

[46] Puri, M., "The Long Term Default Performance of Bank Underwritten Security Issues," Journal of Banking and Finance 18, 397-418, 1994

[47] Puri, M., "Commercial Banks as Underwriters: Implications for the Going Public Process," Journal of Financial Economics 54, 133-163, 1999

[48] Rajan, R., "Insiders and Outsiders: The Choice between Informed and Arm's-Length Debt," Journal of Finance 47, 1367-1400, 1992

[49] Rigobon, R., "Comment to Moel," Economia 2, 258-265, 2001

[50] Ritter, J., "The Costs of Going Public," Journal of Financial Economics 19, 269-281, 1987

[51] Rousseau, P., and P. Wachtel, "Equity Markets and Growth: Cross Country Evidence on Timing and Outcomes," Journal of Banking and Finance 24, 1933-1957, 2000

[52] Saint-Paul, G., "Technological Choice, Financial Markets and Economic Development," European Economic Review 36, 763-781, 1992

[53] Santomero, A. and D. Babbel, Financial Markets, Instruments and Institutions (second edition). Boston: McGraw-Hill, 2001

[54] Saunders, A., "Conflicts of Interest: An Economic View," in I. Walter (ed.) Deregulating Wall Street, New York: John Willey and Sons, 1985

[55] Saunders, A. and I. Walter, Universal Banking in the US, New York: Oxford University Press, 1994

[56] Sharpe, S., "Asymmetric Information, Bank Lending and Implicit Contracts," Journal of Finance 45, 1096-87, 1990

[57] Shockley, R. and A. Thakor, "Bank Loan Commitments: Data, Theory and Tests," Journal of Money, Credit and Banking 29, 517-534, 1997

[58] Titman, S. and B. Trueman, "Information Quality and the Valuation of New Issues," Journal of Accounting and Economics 8, 159-172, 1986

[59] Tufano, P., "Financial Innovation and First-Mover Advantages," Journal of Financial Economics 25, 213-240, 1989.

[60] Walter, I., Deregulating Wall Street. New York: John Wiley and Sons, 1985

[61] Wilhelm, W. and J. Downing, The Information Technology Revolution in Financial Markets. Forthcoming

[62] Williamson, O., "Transaction Cost Economics: The Governance of Contractual Relations," Journal of Law and Economics 22, 233-261, 1979 


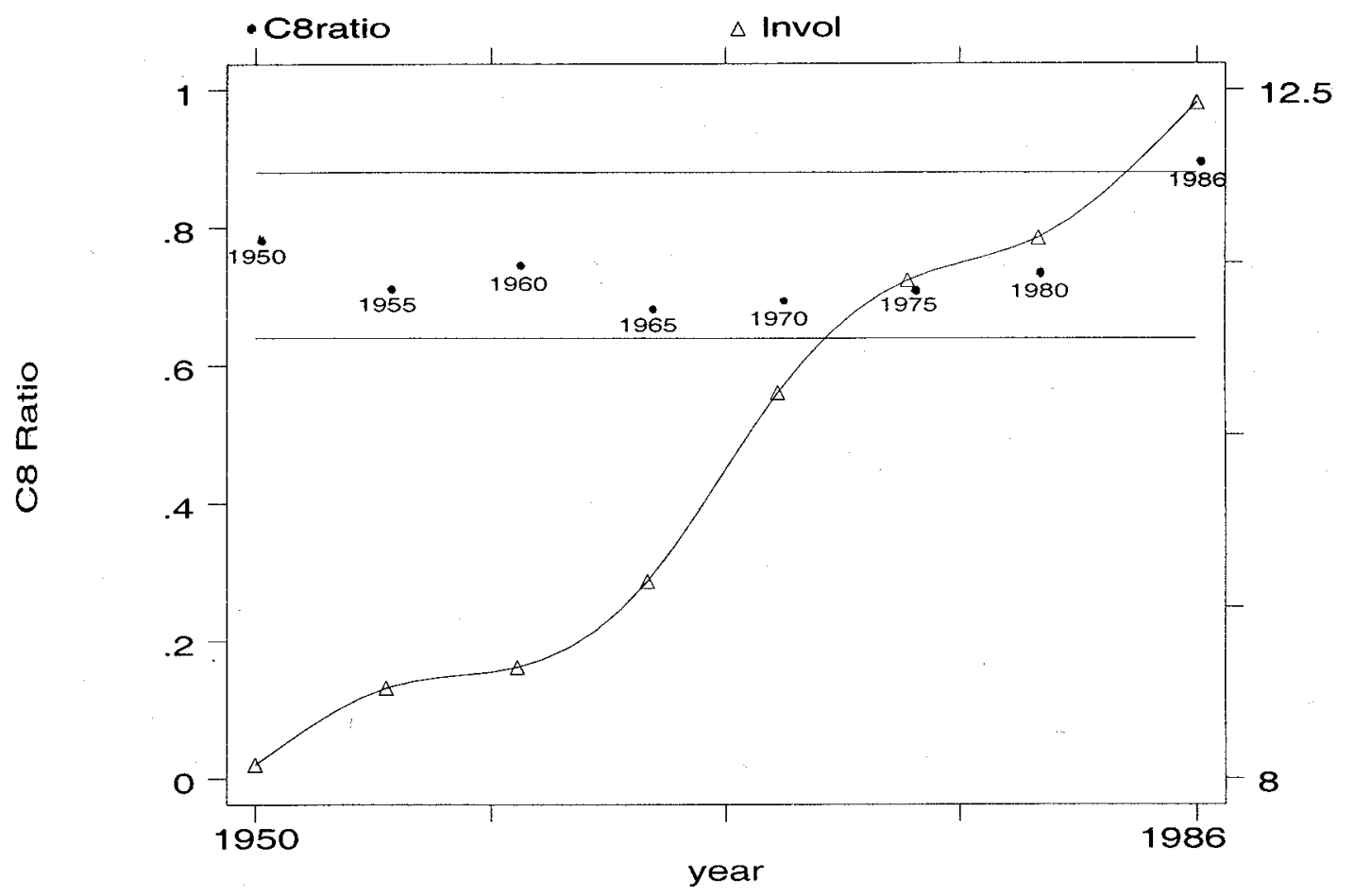

0
0
0
$\vdots$
0
0
$\frac{0}{2}$
0
$>$

Figure 1. Concentration and Volume in Underwriting

Source: Hayes, Spence, and Marks (1983), table 1, and Eccles and Crane (1988), table 5.4.

"C8-Ratio" is the share of total volume of securities underwritten in any given year by the top eight investment banks. Full credit is given to lead manager. "Volume" is the logarithm of total volume of securities underwritten in any given year. 


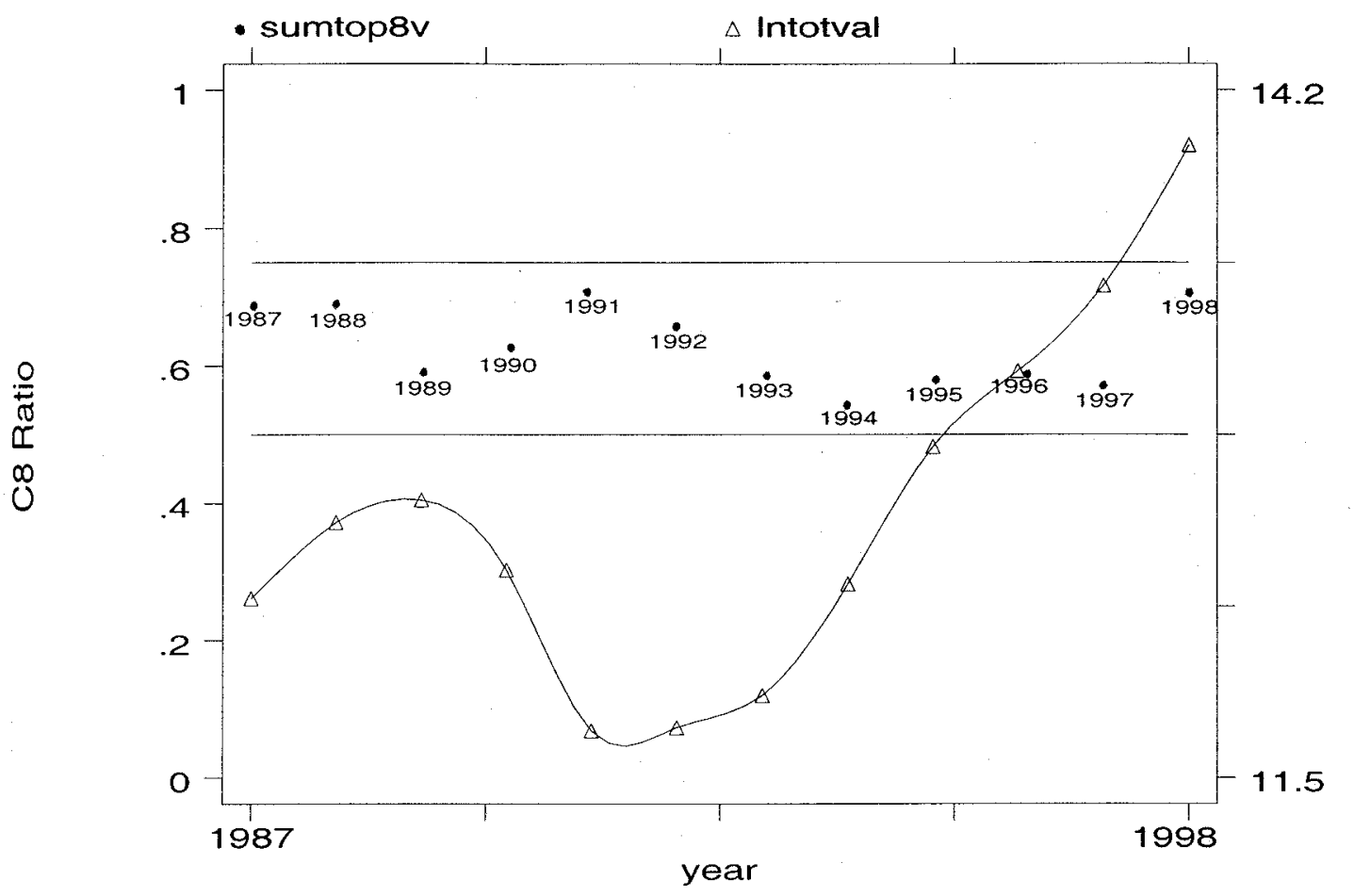

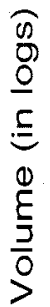

Figure 2. Concentration and Volume in Mergers and Acquisitions Source: Author's processing of data from Securities Data Company. "C8-Ratio" is the share of total deal value of mergers and acquisitions brokered by the top eight investment banks in any given year. Full credit is given to the acquiror's lead bank. The sample of M\&A deals is restricted to those made by firms that do at least three such deals in the 12-year period 1987-1998. 
Table 1a: Leading U.S. Underwriters: All Debt and Equity, 1999

Ranked by dollar volume raised in new issues

\begin{tabular}{|c|c|c|c|c|}
\hline Lead manager & $\begin{array}{l}\text { Dollar Volume } \\
\text { (Millions) }\end{array}$ & $\begin{array}{l}\text { Number of } \\
\text { Issues }\end{array}$ & $\begin{array}{l}\text { Share of } \\
\text { Market }\end{array}$ & $\begin{array}{l}\text { Added } \\
\text { Share }\end{array}$ \\
\hline Merril Lynch & $\$ 332,385$ & 2,000 & 15.9 & 15.9 \\
\hline Solomon Smith Barney & 261,532 & 1,502 & 12.6 & 28.5 \\
\hline Morgan Stanley Dean Witter & 216,421 & 2,253 & 10.3 & 38.8 \\
\hline Goldman, Sachs & 197,615 & 2,063 & 9.4 & 48.2 \\
\hline Credit Suisse First Boston & 177,139 & 1,133 & 8.4 & 56.6 \\
\hline Lehman Brothers & 159,002 & 897 & 7.8 & 64.4 \\
\hline Chase Manhattan & 121,022 & 1,097 & 5.8 & 70.2 \\
\hline J.P. Morgan & 82,639 & 497 & 3.3 & 73.5 \\
\hline Bear, Stearns & 78,695 & 578 & 3.8 & 77.3 \\
\hline Bank of America & 76,605 & 654 & 3.7 & 81.0 \\
\hline \multicolumn{5}{|c|}{$\begin{array}{l}\text { Source: Santomero and Babbel (2001, ch. } 21) \text {. } \\
\text { Note: All credit is given to the lead underwriter. }\end{array}$} \\
\hline \multicolumn{5}{|c|}{$\begin{array}{l}\text { Table 1b: Leading U.S. Underwriters: All Debt and Equity, } 1999 \\
\text { Ranked by disclosed fees }\end{array}$} \\
\hline Lead manager & $\begin{array}{l}\text { Dollar Volume } \\
\text { (Millions) }\end{array}$ & $\begin{array}{l}\text { Number of } \\
\text { Issues }\end{array}$ & $\begin{array}{l}\text { Share of } \\
\text { Market }\end{array}$ & $\begin{array}{l}\text { Added } \\
\text { Share }\end{array}$ \\
\hline Morgan Stanley Dean Witter & $\$ 1,897$ & 2,253 & 15.6 & 15.6 \\
\hline Goldman, Sachs & 1,747 & 2,063 & 14.4 & 30.0 \\
\hline Merril Lynch & 1,474 & 2,000 & 12.3 & 42.3 \\
\hline Solomon Smith Barney & 1,293 & 1,502 & 10.7 & 53.0 \\
\hline Credit Suisse First Boston & 987 & 1,133 & 8.1 & 61.1 \\
\hline Donaldson, Lufkin \& Jenrette & 795 & 436 & 6.6 & 67.7 \\
\hline Lehmann Brothers & 602 & 887 & 5.0 & 72.7 \\
\hline J.P. Morgan & 566 & 497 & 4.7 & 77.4 \\
\hline Bear, Stearns & 369 & 578 & 3.0 & 80.4 \\
\hline Deutsche Bank & 336 & 393 & 3.0 & 83.4 \\
\hline
\end{tabular}

Source: Santomero and Babbel (2001, ch. 21). 
Table 2: 1977-82 IPOs Categorized by Gross Proceeds and Contract Type

\begin{tabular}{|c|c|c|c|c|}
\hline Gross Proceeds (\$) & All Offers & $\begin{array}{c}\text { Firm } \\
\text { Commitment } \\
\text { Offers }\end{array}$ & $\begin{array}{c}\text { Best } \\
\text { Effort Offers }\end{array}$ & $\begin{array}{c}\text { Fraction of } \\
\text { Best Effort } \\
\text { Offers }\end{array}$ \\
\hline 100,000--1,999,999 & 243 & 68 & 175 & 0.720 \\
\hline 2,000,000--3,999,999 & 311 & 165 & 146 & 0.469 \\
\hline $4,000,000--5,999,999$ & 156 & 133 & 23 & 0.147 \\
\hline $6,000,000--9,999,999$ & 137 & 122 & 15 & 0.109 \\
\hline $10,000,000--120,174,195$ & 181 & 176 & 5 & 0.028 \\
\hline
\end{tabular}

Source: Table 2 in Ritter (1987). Gross proceeds categories are based on nominal values. 